\title{
C -1
}

Tissue Guide によるGTR法の病理組織学的研究

1.移植材を併用したGTR法の有用性について 神奈川歯科大学歯周病学講座

○伊海博之、児玉利朗、木次大介、杉山貴志、堤 弘治、伏見 肇、堀 俊雄

Histopathological study of guided tissue regeneration by using Tissue Guide

1.The effect of guided tissue regeneration with graft materials

Dept.of Periodontology, Kanagawa Dental College.

OHiroyuki Ikai, Toshiro Kodama, Daisuke Kitsugi, Takashi Sugiyama,

Kouji Tsutsumi, Hajime Fushimi, Toshio Hori

キーワード : GTR法、移植材、Tissue Guide ${ }^{\mathrm{TM}}$

[目的 ]

現在GTR法は、予知性の高い再生療法として確立されつつあるが、広範な骨欠損に対してはその効果は十 分とはいえない。演者らはGTR法に拉ける歯周組織再生促進の試みとして、牛骨由来のハイドロキシアパタ イト及びアテロコラーダングル複合材を用いたスペースメイキングの併用法について第40回春期歯周病学会 にて発表し、その結果移植材の残存は認められたものの顆粒構造の縮小傾向が観察され、更に周囲組織の再 生が著明に認められた。又、従来の移植材で問題とされた霜根膜由来細胞の歯冠側增殖を阻害する要因は確 認されなかった。そこで本研究は、吸収性膜によるGTR法において長期にわたる観察を行い、その有用性を 病理組織学的に検索した。

[材料及び方法］

実験動物は、ビーグル犬5頭を使用した。

実験材料は、バリアメンブレンとして当教室児玉らの開発した吸収性コラーダン膜（Tissue Guide': 高研 社製）を、移植材としてコラーダン・天然アパタイト複合材（Bone Ject: 高研社製）を使用した。

実験方法は、下類両侧第3前田歯・第4前田歯の歯肉弁を全層弁にて剥離した後、同部の近心根に煩側皮質 骨を含めた垂直的高径 $5 \mathrm{~mm}$ 、近遠心的幅径 $5 \mathrm{~mm}$ の人工的裂開型骨欠損を作製した。作製した骨欠損は露出根 面をルートプレーニングし、セメント質を完全に除去した後、歯肉剥離描爬術に準じて歯肉弁を復位・縫合 したものを对照群（C群）、Bone Jectのみを補填したものをBone Ject群（B群）、Tissue Guideのみで骨欠 損部を被覆したものをTissue Guide群（T群）、Bone Jectを補填しさらにTissue Guideで骨欠損部を被覆した ものをBone Ject-Tissue Guide群 (TB群) とした。実験動物は、術後48週で屠殺し、通法に従って病理組織 標本を作製し病理組織学的に検索を行った。

[結果]

口腔内所見に打いては創のし開や明らかな炎症症状を示したものは全ての群において認められなかった。 病理組織所見に扔いて、対照群は接合上皮の根尖側移動が認められ、新生セメント質及び新生骨の再生は 骨欠損底部付近において䚁察された。T群では接合上皮はCEJ付近で停止し、新生セメント質は择爬根面の2/ 3程度、新生骨は $1 / 2$ 程度まで認められた。B群では接合上皮の根尖側移動はT群と比較してやや根尖側に位置 していたが、新生セメント質の形成に関してはT群と同様の所見が認められた。移植材の顆粒構造は残存し ているものの、顆粒間のすべてに新生骨の形成とその成熟化が観察された。TB群では接合上皮の根尖側移 動及び新生セメント質の形成はT群と同様であったが、新生骨は他の3群より再生量が著明であった。さらに 顆粒構造はB群同様残存し、その縮小化が認められた。

[考察及び結論]

以上の所見より、Bone Ject によりスペースメーキングを行ったGTR法は、再生効果の点で他群に優れた 結果を示した。またBone Jectは術後48週において部分的に周囲組織との置換吸収が観察され、これまで問題 とされた歯根膜由来細胞の歯冠側增殖の阻害や移植材の置換吸収等GTR法の概念に反する要因に対して有利 な効果を示すことが明らかとなった。しかし、Bone Jectの骨への完全な置換吸収を確認するためには更に長 期の観察が必要と考えられる。 
Tissue Guide ${ }^{\mathrm{Tu}}$ によるGTR法の病理組繶学的研究

2.一壁性骬久損モテルにおける有用性について 神奈川科大学周病学埲座

○杉山貫志、児玉利朗、木次大介、伊海博之、堤弘治、伏見等、堀俊雄 Histopathological study of guided tissue regeneration by using Tissue Guide ${ }^{\text {Th }}$ 2.The effect of one wall bone defect model

Deptof Periodontology, Kanagawa Dental College.

OTakashi Sugiyama,Toshiro Kodama, Daisuke Kitsugi,Hiroyuki Ikai, Kouji Tsutsumi, Hajime Fushimi, Toshio Hori

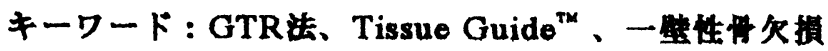

[目的 $]$

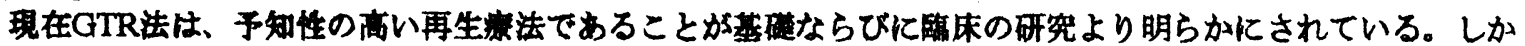

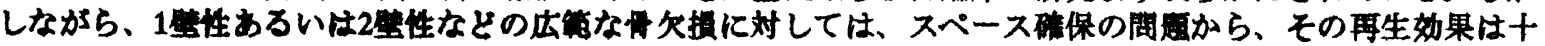

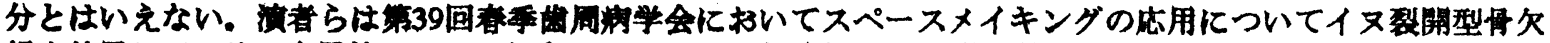

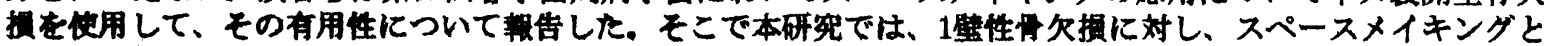

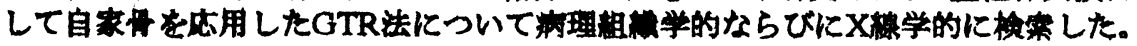

[材料及び方法]

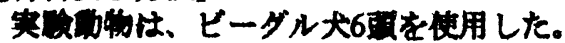

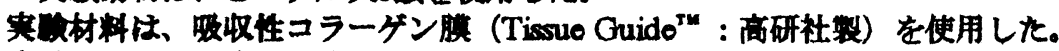

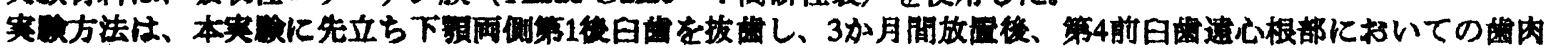

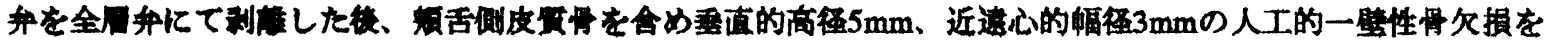

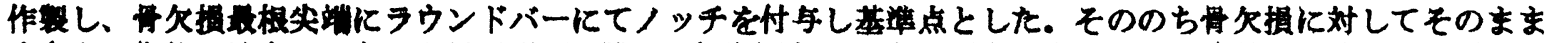

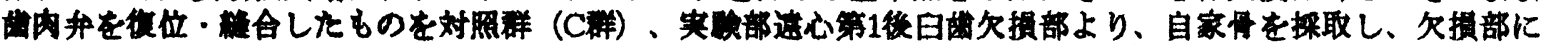

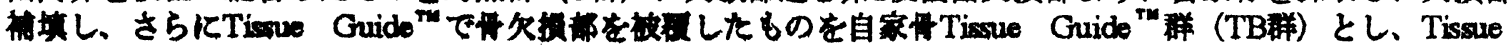

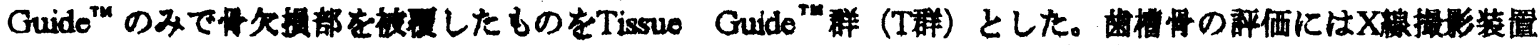

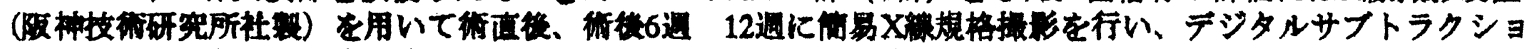

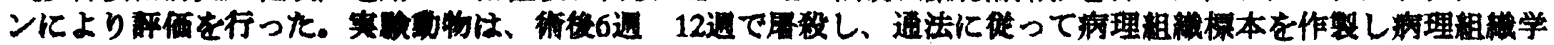
的㳊案を行った。

[結果]

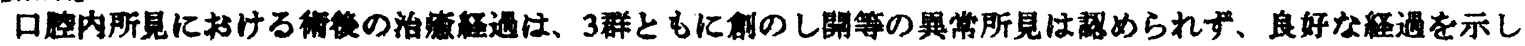

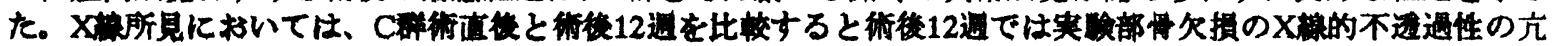

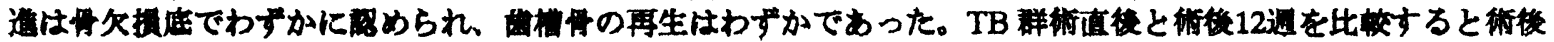

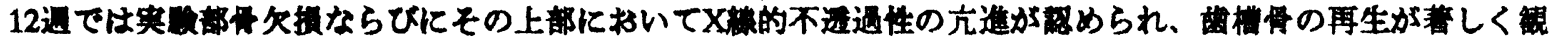

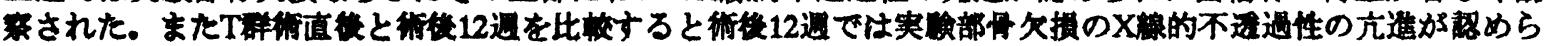

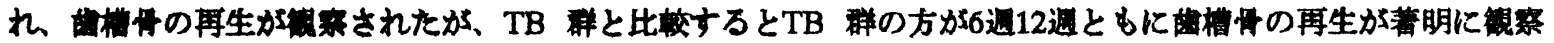
された.

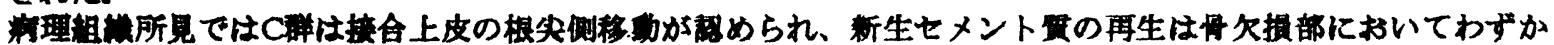

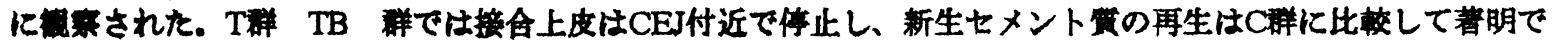
あった。またTB群にいおてアンキローシスや根吸収はほとんど鑹宗されなかった。

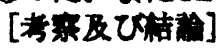

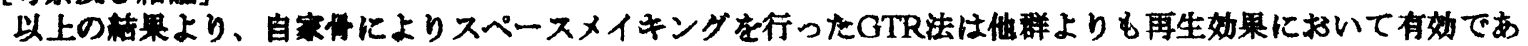

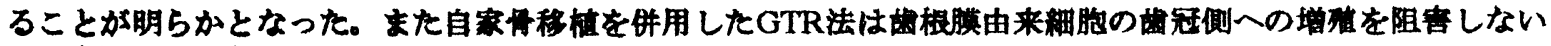
ことも明らかとなった。 
C- 3

Tissue Guide ${ }^{\mathrm{TM}}$ によるGTR法の病理組織学的研究

3.歯周組織の再生量の分析

神奈川歯科大学歯周病学講座

○木次大介、児玉利朗、杉山貴志、伊海博之、堤 弘治、伏見 肇、堀 俊雄

Histopathological study of guided tissue regeneration by using Tissue Guide ${ }^{\mathrm{TM}}$

3. Analysis of periodontal tissue regeneration level

Dept.of Periodontology, Kanagawa Dental College.

O Daisuke Kitsugi, Toshiro Kodama,Takashi Sugiyama, Hiroyuki Ikai, Kouji Tsutsumi, Hajime Fushimi, Toshio Hori

キーワード : GTR法、Tissue Guide ${ }^{\mathrm{TM}}$

[目的 ]

近年、垂直性骨欠損や分岐部病変に対し吸収性及び非吸収性の膜を用いた組織誘導再生法（G T R 法）の 臨床効果に関する報告が数多く行われ、術式や適応症も確立されつつある。しかしながら G T R法による歯 周組織再生量にも限界があり、骨欠損の幅や深さにより再生される歯周組織量は様々である。そこで本研究 ではG T R 法における歯周組織の再生量を検索するために、裂開型骨欠損の幅を一定とし、哚さを軽度、中 等度、重度の 3 群に設定し、病理組織学的に検索した。

[材料及び方法］

実験動物は雑種成犬14頭を用いた。実験材料は吸収性コラーダン膜（Tissue Guide ${ }^{\mathrm{TM}}$ : 高研社製）を使用し た。実験方法はペントバルビタール麻酔下で下顎両側第3、第4前臼歯の歯肉弁を全層弁で剥離した後、同部 の近心根部に煩側皮質骨を含めた近遠心的幅径 $5 \mathrm{~m} \mathrm{~m}$ 、深さ $3 \mathrm{~m} \mathrm{~m}$ （軽度）、6 $\mathrm{mm}$ （中等度）、9 $\mathrm{mm}$ （重度） の 3 種類の裂開型骨欠損を外科的に作製した。作製した骨欠損はルートプレーニング及びデブライドメント の後、骨欠損底に相当する露出根面に計測用ノッチを付与し、実験群はTissue Guideを応用し骨欠損の深さ によりT3群、T6群、T9群の3群を設定した。一方、対照群はなにも入れない状態で歯肉弁を復位縫合し、実 験群と同様に骨 欠損の深さによりC3群、C6群、C9群の3群を設定した。術後6、12週で屠殺し、通法に従っ て病理組織標本を作製し、病理組織学的検索を行った。

[結果]

口腔内所見ではすべての群において創のし開や、明らかな炎症症状を示したものは認められなかった。病 理組織学的観察においては、アンキローシス及び穿下性歯根吸収は全ての群で観察されなかった。対照群

(C3, C6, C9) では6週、12週ともに接合上皮の深部増殖及び歯肉退縮が顕著に認められ、新生セメント質及び 新生骨の再生は骨欠損底部に僅かに観察された。実験群（T3，T6，T9）では術後6週、12週ともに対照群に比 ベ、すべての群において歯肉退縮、接合上皮深部増殖は抑制され、新生骨、新生セメント質は有意に増大し ていた。しかしながら、T3群においては、T6群、T9群と比べ骨再生率が少ない傾向が認められた。

\section{[考察及び結論]}

以上の結果より、軽度、中等度、重度のすべての裂開型骨欠損において、G T R 法により㐘周組織再生が 顕著に認められた。しかしながら、T3群では骨の再生が低いことから、6 $\mathrm{mm}$ 以上の骨欠損においてより効果 的な骨再生が得られるものと考えられるが、今後スペースメイキング材の併用等の検 索も合わせて行い分析 する予定である。 
C -4

根分岐部病変に対するコラーゲン膜を用いたGTR法に関する動物実験評価

奥羽大学歯学部歯科保存学第一講座

○佐藤 純、三辺正人、関野 愉、田代俊男、吉野隆司、岡本 浩

The effect of collagen barrier in GTR treatment of degree III furcation defects.

An experimental study in dogs.

Department of Periodontics, Ohu University, Faculty of Dentistry

OJun SATOH, Masato MinaBe, Satoshi SEKINO, Toshio TASHIRO, Takashi Yoshino, Hiroshi OKamoto

キーワード

GTR 法、自家骨移植、コラーゲン膜

目的

GTR 法は新生骨形成の予知性が低いことから、骨形成を促進する方法との併用法が種々試みられ ている。臨床的には、GTR 法と自家骨移植の併用法が一般的に多く用いられている。吸収性コラーゲ ン膜(Tissue Guide ${ }^{\circledR}$ )を用いた骨棘内欠損に対する動物実験および臨床評価においてその有効性が 報告されている。本研究では根分岐部欠損に対する Tissue Guideを用いた GTR 法および自家骨移 植との併用法の有効性について動物実験評価を行った。

材料と方法

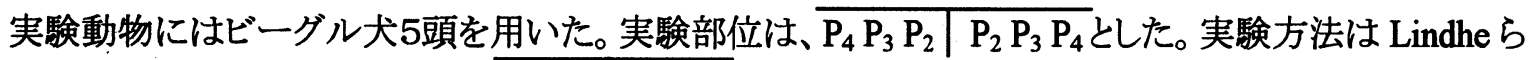
(1995)の方法に基づいて行った。 $\bar{M}_{1} \mathrm{P}_{1} \mid \mathrm{P}_{1} \mathrm{M}_{1}$ を抜歯2ヶ月後に“Key Hole”型而級根分岐部欠損を 形成し、シリコンを注入後、歯肉弁を復位縫合して4週間プラークコントロールを中止した。シリコン除去 後、プラークコントロールを再開し、さらに4週間経過後に GTR 処置を行った。処置群は Flap curettage 群 (C 群)、Tissue Guide 応用群 (TG 群)、Tissue Guide ${ }^{\circledR}$ 自家骨移植の併用群 (TGB) 群とした。処置 後3ヶ月後に安楽死させ、通法に従い固定、脱灰、パラフイン包埋後、近遠心断連続切片を作製、HE 染色後光学顕微鏡観察と組織計測を行った。

\section{結果および考察}

評価は著しい歯肉退縮の認められた 3 ブロック $\overline{\mathrm{P}_{2} \mathrm{P}_{3} \mathrm{P}_{4}}$ を除く7ブロック、各群7歯について検討を行 った。根分岐部欠損の幅 (近遠心根ノッチ間距離)および高さ(ノッチ間中央から Fornix までの距離)に 3群間で有意差は認められなかった。新生セメント質形成量(近遠心根ノッチから最歯冠側端距離の平 均值)は TG 群および TGB 群が C 群に比較して有意に高い值を示した。新生骨形成量(近遠心根ノッ チ間中央部の高さ)は TG 群および TGB 群が C 群に比較して有意に高い值を示し、なかでも TGB 群 が最も高い值を示した。本研究結果から、根分岐部病変におけるコラーゲン膜を用いた GTR 法の有効 性が示唆された。特に根分岐部病変は、骨再生が十分に期待できない部位であることから、再生療法 しして GTR 法と自家骨移植を併用することは合理的であると考えられる。さらに移植骨の吸収、新生骨 への置換および自家骨移植が根面の付着様式に及ぼす影響について検討考察を行う予定である。 
C -5

GTR 法における抗菌療法に関する臨床的検討

奥羽大学歯学部歯科保存学第一講座

○吉野隆司、三辺正人、鈴木 史彦、関野愉、田代俊男、佐藤純、岡本 浩

Clinical evaluation of antibiotic treatment on GTR.

Department of Periodontics, Ohu University, Faculty of Dentistry

OTakashi Yoshino, Masato Minabe, Fumihiko SuZUKI, Satoshi SEkINo, Toshio TaShIRo, Jun SatoH, Hiroshi OKAMOTO

キーワード

GTR 法、抗菌療法、e-PTFE 膜

目的

非吸収性膜(PTFE 膜)を用いた GTR 法の予知性に影響を及ぼす因子の一つとして、膜の露出と污染 の問題が挙げられる。欧米では、GTR 部位以外からの菌の再定着や、GTR 後の $A$. actinomycetemcomitans 菌(A.a)の残存を抑制する目的で、GTR 法と抗生物質の経口および局所投与 の併用法が有用視されている。本研究では、PTFE 膜を用いた GTR 法の術前、術後処置としての抗生 物質投与の有効性を明らかにする目的で臨床的検討を行った。

材料と方法

成人性歯周炎と診断された 20 名(34 60 歳、男性 14 名、女性 6 名)の $2 、 3$ 壁性骨内欠損 26 部位を 対象とし、10 名 14 部位を通常の GTR 処置群(Cont 群)、10 名 12 部位を GTR と抗生物質投与の併用 群(Exp 群)とした。抗生物質は、術前処置として、ミノサイクリン軟亳(ペリオクリン®)の局所投与(1 回/W、 4 回投与)を行い、術前から術後処置として、ミノサイクリンの経口投与(術前 3 日間、術後 4 日間 $200 \mathrm{mg} /$ 日)を行った。GTR 術前、術中、術後 2 週、6 週(膜除去時)、3 力月、6 力月時に臨床診查(PCR、 PI、GI、PD、BOP、PAL、膜の露出の判定、骨欠損計測、規格X線撮影)と細菌検査(酵素活性テスト; ペリオチェック 、DNA プローブ)を実施した。また、除去した膜の一部については膜内面の SEM 観察 を行い、Santics ら(1996)の方法により歯冠側およ根尖側領域の膜污染について定量評価を行った。

結果

Exp群とCont群で術前の probing depth (PD)、probing attachment level (PAL)、骨欠損深さ(DBD)に有 意差は認められなかった。術後 6 力月時における PD、probing attachment gain (PAG)は Exp 群が Cont 群に比較して有意な改善が認められた(PD; Exp 群 1.8mm、Cont 群 2.6mm、PAG; Exp 群 3.3mm、Cont 群 2.1mm)。また、PAL に対する PAG の比率(\% gain of potential attachment increase; Nowzari ら 1995) は Exp 群 45\%、Cont 群 30\%、DBD に対する PAG の比率(V-rAG; Christgau ら 1995)は Exp 群 70\%、 Cont 群 50\%で、いずれも有意差が認められた。ペリオチェックによる陽性率の比較では、術後 3 力月時 にCont 群が Exp 群に比較して高い比率を示した。除去した膜内面の SEM 評価では、Cont 群が Exp 群に比較して、歯冠側領域の污染率が有意に高いことが明らかとなった。

考察および結論

非吸収性膜を用いた GTR 法の予知性を高める上で、抗生物質投与を併用することの有用性が臨床 的に明らかとなった。これは裏を返せば膜設置に起因する污染のコントロールの困難性を意味してい る。A. $a$ 菌を中心とした歯周病関連性細菌の出現頻度と臨床結果の関連性については検討中である。 
C- 6

上部構造接合部と歯肉辺縁の位置関係が周囲組織におよぼす影響に関する 歯周病学的観察

医療法人伊東会伊東歯科医院＼cjkstart炌州歯科大学保存学第二講座

O村上慶 西村賢二 渡辺諭 田中俊憲 伊東泰蔵 伊東隆利 $*$ 内藤徹 $*$ 横田誠 Periodontal obseravation concerning the effect of the position of Implant shoulder on the surrounding tissue

Medical Corporation Itoh-Kai Itoh Dental Clinic

*Department of Periodontology and Endodontology, Kyushu Dental College

OKei Murakami, Kenji Nisimura, Satosi Wakanabe, Tosinori Tanaka,

Taizou Itoh, Takatosi Itoh, *Tooru Naitou, *Makoto Yokota

キーワード 上部構造接合部 歯肉辺縁 菌周病学的観察

(目的)インプラントを長期的に安定した状態で機能させるためには、継続的なメインテナンスを行う ことが不可欠である。今回われわれはインプラント周囲の歯肉辺縁の位置に着目し、歯肉辺縁が上部構 造接合部より低位にある場合と高位にある場合でインプラント周囲組織がその影響をどのように受け るかを歯周病学的指標を用いて検討し、若干の知見を得たので報告する。

(観察対象および方法)観察を行ったインプラントは1993年から1996年3月までに同一術者によって植 立され、1997年6月にインプラント定期検査のため来院された22症例67本である。インプラントはITIBonef it2パートスクリュウタイプであり、上部構造を植立後およそ3カ月経過した後オクタシステムに て装着した。観察方法は、まず上部構造接合部が歯肉辺縁より高位に位置するものを( 郡)、同レベルの ものを(0群)、低位に位置するものを(情)と分類し、インプラント体の近心、遠心、煩側、舌側、4カ所に ついて菊周病学的指標を計測し有意差の検定を行った。歯周病学的指標はPlaque Index (P1I), Bleed ing on Probing (BOP), Periotron値, Probing Pocket Depth (PPD), Probing Attachment Lebel (PAL) である。

(結果)上部構造接合部之歯肉辺縁の位置関係の割合については、(群)が最も多く $41.0 \%(110$ 力所)を 占め、次いで(0群)31.0\%(83力所)、(群)28.0\%(75力所)の順であった。P1IはP1I指数が0を示した部位 が最も多く49.2\%(132力所)を占めた。1を示した部位は34.2(91力所)であり、2あるいは3を示した部位 は16.85\%(45力所)であった。これを菊肉辺縁別にみると(-群)と(群)で0を示すところが多かったが、 (0群)では1を示すところが多くみられた。しかし各群間での有意差は認められなかった。BOPについて0 の值をとる割合は(群)において80.9\%、(0群)において68.7\%、(-群)において64.0\%であり、(群)と(+ 群)に5\%未満の危険率で優位差を認めた。Perotron值については、20以下の值を示す部位は(-群)で89. 1 \%、(0群)で86.7\%、(伊群)で45.3\%であり、(群)と(十群)、(0群)と(十群)において1\%のが危険率で有意差

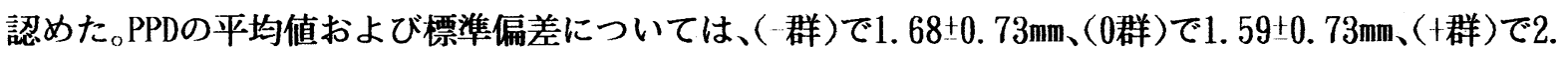
62+0.84であり、(一群)と(十群)、(十群)と(0群)において1\%の危険率で有意差が認められた。PALの平均値

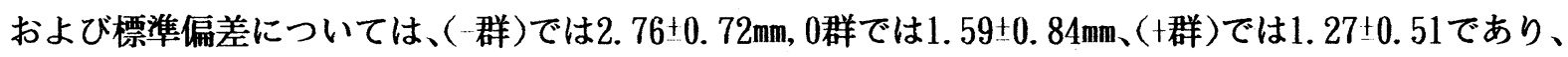
(-群)と(0群)、(0群)と(十群)のいずれにおいても1\%の危険率で有意差を認めた。

(考察)インプラントの周囲組織を考えた場合, 天然齿における補緅治療と同様に上部構造との接合部 が組織内に入ると周囲組織に影響があると思われる。今回上部構造接合部に対する菊肉辺縁の位置と 歯周学的指標との関係について検索を行った。今回の観察では上部構造はすべてオクタシステムを使 用していることから接合部の精度はかなり高いと考えられるが、やはりショルダーが歯肉匄縁より低 位に位置する方がBOP, Periotron值において高い值を示し、歯周病学的に影響があるといえた 
C- 7

Recombinant Human BMP-2を用いた歯周組織再生に関する研究

-PLGA/ゼラチン複合体を担体とした、サル下顎且度分岐部骨欠損への応用 -

北海道大学歯学部歯科保存学第 2 講座

○本郷 興人、伊藤 豊、小田島 朝臣、山路 公造、加藤 熙

A Study of periodontal regeneration by recombinant human BMP-2

- With PLGA/gelatin complex as a carrier to the degree III furcation defects in MonkeysDepartment of Periodontology and Endodontology , Hokkaido University School of Dentistry

OOkito HONGO,Yutaka ITO, Tomoomi ODAJIMA, Kozo YAMAJI and Hiroshi KATO

キーワード:リコンビナントヒトBMP2（rhBMP-2）、分岐部且度骨欠損、再生

\section{【緒言】}

これまで当教室では、リコンビナントヒトBMP-2（rhBMP-2）の菌周治療への応用に関する基整的研

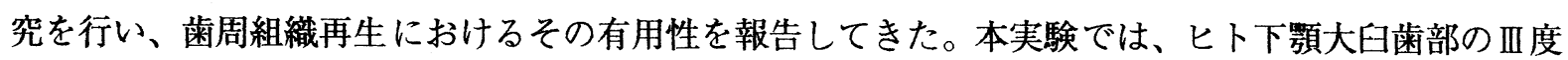
分岐部骨欠損への応用を想定して、开ル下頻大白歯の根分岐部歯槽骨に外科的に骨欠損を作製した後、 同部にPLGA/ゼラチン複合体を担体としてrhBMP-2の移植を行い、菌周組織再生を検討した。

\section{【材料と方法】}

実験には成体のカニクイザル2頭の下靧両側第 1 、第 2 大臼菌の根分岐部、計8部位を用いた。術前 2 週間ブラッシングとスケーリングを行って臨床的に健康な歯周組織を確立させた後、麻酔下で全層 弁を剥離し、㚘舌側の歯槽骨をCEJより根尖側 $3 \mathrm{~mm}$ の高さまで近橾心の隅角部を含めて削除した。さ らに分岐部内の骨を削除して II 度の分岐部骨欠損を作製し、露出させた根面のセメント質をバーとス ケーラーで除去した。rhBMP-2の担体には、（株）山之内製菜より提供をうけたスポンジ状のゼラチ ン・ポリ乳酸グリコール酸複合体を用いた。実験群にはrhBMP-2溶液を担体に含浸 $(100 \mu \mathrm{g} / 100 \mu \ell)$ させ凍結乾燥して移植し、対照群は何も移植せず外科処置のみとした。観察期間は 12 週間とし、各週 毎に臨床的診查および规格X線写真撮影による骨再生の評価を行った。

実験期間終了後被験動物をsacrificeし、通法に従って組織標本を作製して光顕観察を行った。

\section{【結果と考察】}

臨床所見：観察期間中の治癒はほとんどの部位で良好であった。しかし実験群の1部位で分岐部の 露出が観察され軽度の炎症が認められた。

X線所見：実験群、対照群ともにX線不透過性の元進が観察された。しかし両群間には、不透過性立 進の速度㧍よび観察期間終了時の不透過度に明らかな差は認められなかった。

組織学的所見：rhBMP-2を移植した実験群では骨とセメント質の著明な再生が観察された。さらに 再生した骨と歯根面とのアンキローシスは観察されなかった。一方対照群においても、骨およびセメ ント質の再生が観察されたが、その程度には差が認められた。

これらのことから下類根分岐部血度の骨欠損にrhBMP-2をPLGA/ゼラチン複合体を担体として応用す る治療法が有効であることが示唆された。 